Original Research Paper

\title{
Effect of Calcium Carbonate Addition on The Growth and Feed Conversion Ratio of Gourami (Osphronemus goramy) Seed
}

\author{
Dewi Nur'aeni Setyowati ${ }^{*}$, Anita Prihatini Ilyas², Awan Dermawan², Sanca \\ Rahmatullah $^{2}$ \\ ${ }^{1}$ Aquaculture Study Program, Faculty of Agriculture, University of Mataram, Mataram, Indonesia \\ ${ }^{2}$ Vocational of Aquaculture, University of Mataram, Bima, Indonesia
}

\author{
Article History \\ Received : December 05 ${ }^{\text {th }}, 2021$ \\ Revised : December 15 $5^{\text {th }}, 2021$ \\ Accepted : December $25^{\text {th }}, 2021$ \\ Published : January $16^{\text {th }}, 2022$ \\ *Corresponding Author: \\ Dewi Nur'aeni Setyowati, \\ University of Mataram, Mataram, \\ Indonesia,; \\ Email: dewins@unram.ac.id
}

\begin{abstract}
Gourami is one of the main freshwater fish commodities which has a high economic value. One of the efforts that can be made to increase the productivity of gourami is the provision of macromineral in the form of calcium carbonate $\left(\mathrm{CaCo}_{3}\right)$. This study aimed to determine the effect of calcium on productivity that would be seen through the growth rate and feed conversion ratio of gourami seed. The study consisted of five doses of calcium carbonate, each of which was repeated three times. As for treating the doses of calcium carbonate, including $1\left(0 \mathrm{mg} / \mathrm{L} \mathrm{CaCO}_{3}\right), 2(150 \mathrm{mg} / \mathrm{L}$ $\left.\mathrm{CaCO}_{3}\right), 3$ (200 mg / $\left.\left.\mathrm{L} \mathrm{CaCO}_{3}\right), 4(250 \mathrm{mg} / \mathrm{L}) \mathrm{CaCO}_{3}\right)$ and $5(300 \mathrm{mg} / \mathrm{L}$ $\mathrm{CaCO}_{3}$ ). The maintenance medium is added with a salinity of $3 \mathrm{ppt}$ in order to save metabolic energy through an osmoregulation mechanism so that the available energy is expected to be used to increase growth. The result or absolute weight growth was not significantly different based on the analysis of variance and linier regression analysis. The analysis of variance showed that no significant different for survival rate of all treatments. The value of feed conversion ratio was not significantly different based on analysis of variance and linier regression analysis. Addition of calcium carbonate did not give significant difference in the absolute weight growth, survival rate, and feed conversion ratio of gourami seed.
\end{abstract}

Keywords: calcium carbonate, gourami, growth

\section{Introduction}

Gourami (Osphronemus gourami) is a fish with high economic value which is one of the main commodities of aquaculture in Indonesia. The problem faced is that these fish have a relatively slow growth rate (Budi, 2014; Nugraha et al., 2020). To reach a size of $200 \mathrm{~g} /$ head from a size of $15 \mathrm{~g} /$ head it takes 120 days, in the first stage of enlargement with a protein content of 20$26 \%$ while in the second stage of enlargement from a size of $200 \mathrm{~g} /$ head to reach a consumption size of $500 \mathrm{~g} /$ head takes 150 days (SNI 2006). This is an obstacle faced by cultivators in order to increase the productivity of gourami. One of the efforts to increase the productivity of gourami is the addition of minerals in the form of calcium.

Salinity is closely related to the osmotic and ionic pressure of water. The salinity medium affects the osmoregulation system in the fish body. Freshwater fish body fluids have a higher pressure (hyperosmotic) than their environment so they tend to take salts in the form of $\mathrm{Na}+$ and Cl- ions from the water through a diffusion mechanism. The $4 \mathrm{~g} / \mathrm{L}$ salinity environment in catfish farming will make the conditions close to isoosmotic so that it reduces energy use for osmoregulation and then diverted it for growth. In order for fish organ cells to function properly, these cells must be in a fluid media (extracellular) which has the same ionic composition and concentration as the fluid in cells (intracellular) (Fujaya, 1999).

One of the efforts to increase productivity through optimization of growth of gourami is the addition of minerals in the form of calcium. According to Boyd (1982) in Heriadi et al. (2016), calcium is also needed by fish for the osmoregulation process that occurs in the fish's 
body and the environment and is important for bone formation and the formation of the outer skeleton of crustaceans. Calcium is an essential mineral that is needed in sufficient quantities. Calcium needs can be met with the addition of lime. Liming materials that are often used for agriculture are $\mathrm{CaCO} 3$ (calcite), $\mathrm{CaMg}$ (CO3) 2 (dolomite), and other types of lime such as $\mathrm{Ca}$ $(\mathrm{OH}) 2$ and $\mathrm{CaO}$. The available lime content in quicklime $(\mathrm{CaO})(71 \%)$, extinguished lime $(\mathrm{Ca}$ $(\mathrm{OH}) 2$ ) (54\%), and agricultural lime (CaCO3) (40\%). Therefore, the optimal dose of lime to increase the growth of gourami needs to be known.

\section{Material and Methods}

\section{Time and Place}

This research was conducted from August to September 2019 for 60 days, taking place in the wet laboratory of the Aquaculture Study Program Vocational Program, Mataram University, PDD, Bima Regency.

\section{Tools and Materials}

The tools and materials used in this study were aquariums with a size of $50 \times 30 \times 30 \mathrm{~cm} 3$, pipes for recirculation system installations, blowers, $\mathrm{pH}$ meters, DO meter, thermometer, refractometers, calcium carbonate powder, sea water, buckets, ditches, scales, digital and a ruler.

\section{Research Method}

The method used in this study is an experimental method. Experimental research is research that carried out on variables whose data does not yet exist, so it needs to be done manipulation process through giving certain treatment to the subject research which is then observed/measured its impact (future data) (Jaedun, 2011).

\section{Research Design}

This study used linear regression analysis with five treat doses of calcium carbonate. Where each treatment was repeated three times. P1: 0 mg/L CaCO3, P2: 150 mg/L CaCO3, P3: $200 \mathrm{mg} / \mathrm{L} \mathrm{CaCO} 3, \mathrm{P} 4: 250 \mathrm{mg} / \mathrm{L} \mathrm{CaCO} 3$, and $\mathrm{P} 5: 300 \mathrm{mg} / \mathrm{L} \mathrm{CaCO} 3$.

\section{Research Procedure}

The containers in the form of an aquarium were washed with soap, then rinsed with clean water and left to dry. The media for keeping gourami was freshwater $(0 \mathrm{ppt})$ with the addition of 3 ppt salinity obtained from the addition of salt. The media water was deposited first so that the remaining dirt goes to the bottom and then filtered. Media water was then collected in a water reservoir and aerated for three days.

The fish used in this study were gourami seeds with a length of $3-5 \mathrm{~cm}$. The stocking density for each container was 20 individuals. The selected fish are healthy seeds, which are characterized by agile movements and are not deformed. Before being put in a rearing container, the fish are acclimatized for one day without feeding with the aim of adjusting to the new environment.

Fish were stocked with a density of 20 fish per aquarium on a maintenance medium with a salinity of 3 ppt. The lime used is $\mathrm{CaCO} 3$ in powder form. $\mathrm{CaCO} 3$ lime was added to the aquarium according to the respective doses in the treatment medium. During the maintenance period, the fish are fed in the form of pellets twice a day in the morning at 09.00 am and $04.00 \mathrm{pm}$ in the afternoon as much as $5 \%$ of the biomass weight with a protein content of $25 \%$. Growth sampling and water quality control carried out once a week during the maintenance period. Water entry into the maintenance container was only carried out when there was evaporation.

\section{Research Parameters}

\section{Absolute Growth Weight}

The total body length of the gourami is measured once a week using a ruler. Absolute length growth is calculated using the Effendie (1997): Pm = Lt - L0, with $\mathrm{Pm}=$ absolute length growth $(\mathrm{cm}), \mathrm{Lt}=$ the final average length $(\mathrm{cm})$, and $\mathrm{LO}=$ initial average length $(\mathrm{cm})$.

\section{Survival Rate}

The survival rate (SR) is the percentage of the number of live fish at the end of maintenance compared to the number of fish at the beginning of stocking which is stated in the following Effendi (1979) cit Setyowati et al. (2007): SR = $(\mathrm{Nt} / \mathrm{No}) \times 100 \%$, with $\mathrm{SR}=$ degree of survival $(\%), \mathrm{Nt}=$ Number of live fish at the end of 
maintenance, and No $=$ Number of fish at the beginning of maintenance.

\section{Feed Conversion Ratio}

The feed conversion ratio is calculated using the formula (Kordi, 2012): $\quad F C R=\frac{\mathrm{F}}{(\mathrm{Wt}+\mathrm{Wd})-\mathrm{Wo}}$ with $\mathrm{Wt}=$ individual average weight at time $\mathrm{t}(\mathrm{g})$, $\mathrm{Wd}=$ total biomass of fish that died during the experiment $(\mathrm{g}), \mathrm{Wo}=$ individual average weight at the start of maintenance $(\mathrm{g})$, and $\mathrm{F}=$ amount of feed eaten $(\mathrm{g})$

\section{Statistic Analysis}

The absolute wight growth, survival rate, and feed conversion ratio were analyzed by Analysis of Variance and Analysis of Regression. The water quality were analyzed with descriptive analysis.

\section{Results and Discussion}

\section{Absolute Weight Growth}

The data of absolute weight growth was presented in figure 1 . The highest weight was obtained in treatment P5 (17 g). And the lowest weight was obtained in treatment P4 $(7 \mathrm{~g})$. But based on analysis of variance showed that no significant different for all treatment.

Table 1. Absolute Weight Growth of Gourami

\begin{tabular}{|c|c|}
\hline Treatment & Absolute Weight Growth (g) \\
\hline P1 & $11^{\mathrm{a}}$ \\
\hline P2 & $10^{\mathrm{a}}$ \\
\hline P3 & $12^{\mathrm{a}}$ \\
\hline P4 & $7^{\mathrm{a}}$ \\
\hline P5 & $17^{\mathrm{a}}$ \\
\hline
\end{tabular}

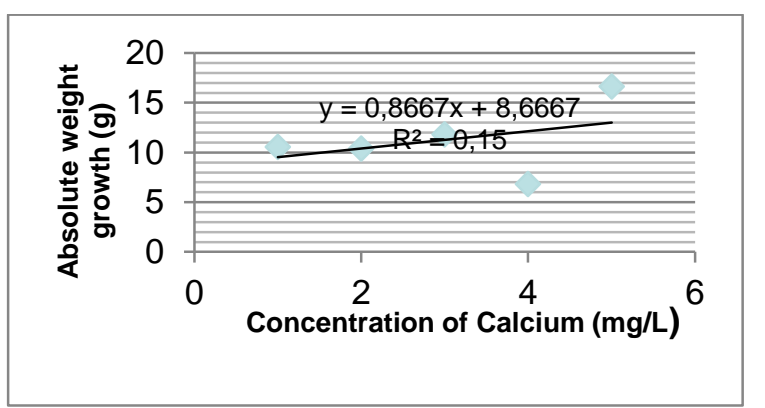

Figure 1. Regression Analysis of Absolute Weight Growth
The regression analysis showed that the result of $\mathrm{R}^{2}$ on concentration of calcium and absolute growth 0.15 .

\section{Survival Rate}

Table 2 gave information of the survival rate of gourami. The highest value of survival rate was in treatment P5. And the lowest value of survival rate was in treatment $\mathrm{P} 1$.

Table 2. Survival Rate of Gourami

\begin{tabular}{|c|c|}
\hline Treatment & Survival Rate (\%) \\
\hline P1 & $57^{\mathrm{a}}$ \\
\hline P2 & $63^{\mathrm{a}}$ \\
\hline P3 & $67^{\mathrm{a}}$ \\
\hline P4 & $60^{\mathrm{a}}$ \\
\hline P5 & $83^{\mathrm{a}}$ \\
\hline
\end{tabular}

The analysis of variance showed that no significant different for all treatment. And the linier regression analysis showed that the $\mathrm{R}^{2}$ was 0.5799

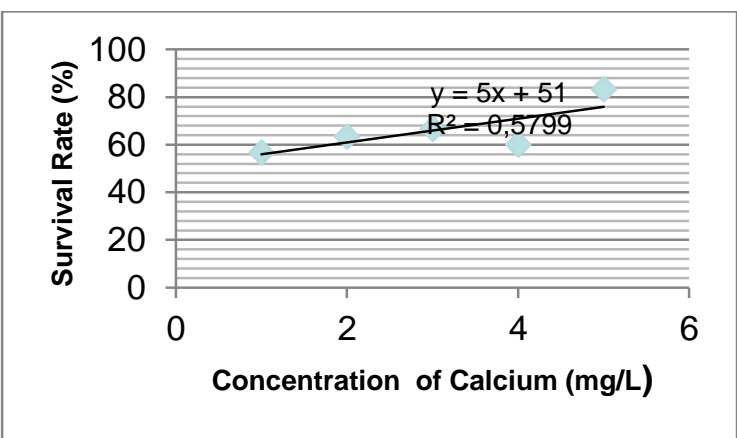

Figure 2. Regression Analysis of Survival Rate

\section{FCR (Feed Conversion Ratio)}

The value of FCR were $0,4-0,9$. The lowest value of FCR was treatment P5, and the biggest value of FCR was traetment P4. But the value was not significantly different based on analysis of variance and linier regression analysis.

Table 3. FCR of Gourami

\begin{tabular}{|c|c|}
\hline Treatment & Feed Conversion Ratio (FCR) \\
\hline P1 & $0.6^{\mathrm{a}}$ \\
\hline P2 & $0.8^{\mathrm{a}}$ \\
\hline P3 & $0.5^{\mathrm{a}}$ \\
\hline P4 & $0.9^{\mathrm{a}}$ \\
\hline P5 & $0.4^{\mathrm{a}}$ \\
\hline
\end{tabular}




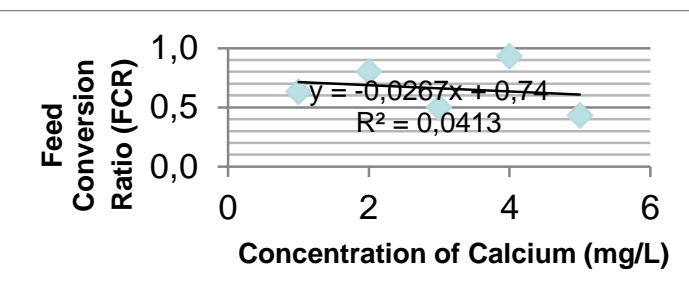

Figure 3. Regression Analysis of FCR

\section{Water Quality \\ The water quality measured in this research were temperature, $\mathrm{pH}$ and Dissolved Oxygen (DO). The temperature range between 27.6-30. $4^{\circ} \mathrm{C}$, the $\mathrm{pH}$ range were 8.4-9.0 and the DO range were $3.9-5.0 \mathrm{mg} / \mathrm{L}$.}

Table 4. Water Quality

\begin{tabular}{|c|c|c|c|}
\hline Treatment & Temperature $\left({ }^{\circ} \mathrm{C}\right)$ & $\mathrm{pH}$ & DO $(\mathrm{mg} / \mathrm{L})$ \\
\hline P1 & $27.6-30.2$ & $8.4-9.0$ & $4.0-4.6$ \\
\hline P2 & $27.6-30.4$ & $8.5-9.0$ & $4.0-4.7$ \\
\hline P3 & $27.7-30.0$ & $8.7-9.0$ & $4.0-5.0$ \\
\hline P4 & $27.7-29.9$ & $8.7-8.9$ & $4.2-4.6$ \\
\hline P5 & $27.7-30.2$ & $8.5-8.9$ & $3.9-4.8$ \\
\hline
\end{tabular}

\section{Discussion}

\section{Absolute Weight Growth}

The result or absolute weight growth was not significantly different based on the analysis of variance and linier regression analysis (Table 1 and Figure 1). The results of linear regression analysis on absolute weight growth showed that the value did not differ between treatments because the R2 value was 0.15 . According to Gomez and Gomez (2007), a good / positive value is if $\mathrm{R}^{2}$ approaches to 1 . Calcium is needed for the body's skeletal formation. Calcium also acts as an enzyme activator. The addition of mineral supplements to feed can increase fish growth (Halver and Hardy, 2002). Deficiency of calsium can give effect to the growth and bone mineralization (Hossain and Yoshimatsu, 2014). However, the results showed that the addition of calcium had no effect on increasing fish weight. This is due to the fact that gourami is a slowgrowing fish, so that the difference in growth is not significant between treatments. Sitanggang and Sarwono (2007) in Wibawa et al. (2018) stated that gourami growth was relatively slow both in the seed maintenance and enlargement phases. The experiment of Kelentarian et al. (2013) and Liang et al. (2017) showed that the dietary calsium had no significant effect on the growth of fish. But, Hossain and Furuichi (2000) in Zainudin (2010) stated that addition of calsium in the feed is necessary for the growth of Japanese flounder, black sea bream, and redlip mullet. Hastutui et al. (2016) also stated that addition of calsium is necessary for the grotwh of freshwater tambaqui.

\section{Survival Rate}

The result of analysis of variance and regression analysis showed that the addition of calsium didn't give effect for survival rate of gourami with the range of survival rate are $57 \%$ to $83 \%$. The value of $\mathrm{R}^{2}$ in linier regression analysis was 0.5799. Based on Sembiring (1995), the effect will be significant if the value of $\mathrm{R}^{2}$ approching to 1 . e. The survival data obtained during the study were $57-83 \%$. According to SNI (2000), survival for gourami nurseries is $60-80 \%$. The data on the survival results showed that the addition of calcium could make better for survival rate of gourami. It was different with the result of Liang et al (2018), that calcium did not give effect for fish survival rate. Hastuti et al (2014) also stated that the addition of calsium in the water with salinity didn0t give effect for survival rete of Pangasius sp.

\section{FCR (Feed Conversion Ratio)}

The value of FCR in the gourami cultivation are less than 1 , it mean that the fish can effective use feed for the growth. Fry et al. (2018) gave a fact that FCR for aquaculture species is lower than cattle and pig with the value between 1.0-2.4. The smaller the FCR value, the more optimal the feed will be used by the fish body for growth. The FCR value of 0.4-0.9 means that every 0.4-0.9 $\mathrm{g}$ of feed produces a weight gain of $1 \mathrm{~g}$. This value is still higher than the study by Anti et al. (2018) who obtained FCR 
values of 2.35-2.60 for gourami which were fed with moringa leaf enrichment.

\section{Water Quality}

The temperature in maintenance is still in the normal range because the value is 27.6-30.2. According to SNI (2000), the optimal temperature for gourami is $25-30^{\circ} \mathrm{C}$. The $\mathrm{pH}$ value in this study shows an alkaline $\mathrm{pH}$ of 8.5 9.0. Calcium in the water will react with $\mathrm{H}^{+}$so that the $\mathrm{pH}$ will increase. (Boyd, 1982 in Heriadi et al., 2016). According to SNI (2006), the optimal $\mathrm{pH}$ range for gourami maintenance is 6.5-8.5. The $\mathrm{pH}$ value during the study showed a rather high upper listmit value of 9.0. The Dissolved oxygen result is still normal for the fish to survive.

\section{Conclusion}

Addition of calcium carbonate did not give significant difference in the absolute weight growth, survival rate, and feed conversion ratio of gourami seed.

\section{Acknowledgement}

We thanks to PNBP of Vocational Program, Bima, University of Mataram that supported this research

\section{References}

Budi, D. S. (2014). Respons Pertumbuhan Benih Ikan Gurami (Osphronemus goramy) yang Diberi Pakan dengan Kadar Protein Berbeda dan Diperkaya Hormon Pertumbuhan Rekombinan. Sekolah Pascasarjana Institu Pertanian Bogor. 56p.

Effendie, M. I. (1997). Metode Biologi Perikanan. Yayasan Dewi Sri, Bogor.

Fujaya Y. (1999). Fisiologi Ikan. Rineka Cipta. Jakarta.

Fry, J. P., Mailoux, N. A., Love, D. C., Milli, M. C., \& Cao, L. (2018). Feed conversion efficiency in aquaculture: do we measure it correctly? Environ. Res. Lett. 13. https://doi.org/10.1088/17489326/aaa273.
Gomez, K., A. and Gomez, A., A. (2007). Prosedur Statistik untuk Penelitian Pertanian. UI Press. Jakarta.

Halver, J. E. \& Hardy, R. W. (2002). Fish Nutrition. Third Edition. Academic Press. USA. 805p.

Hastuti, Y. P., Yudistira, C., Nirmala, K., Nurussalam,W., \& Faturochman, K. (2016). Pemberian $\mathrm{CaCO} 3$ pada media bersalinitas $3 \mathrm{~g} / \mathrm{L}$ untuk pertumbuhan ikan bawal air tawar Jurnal Akuakultur Indonesia 15 (1), 32-40 (2016) DOI: 10.19027/jai.15.32.40.

Hastuti Y. P., Faturochma,K., \& Nirmala, K. (2014). Kalsium Karbonat pada Media Bersalinitas untuk Pertumbuhan Benih Ikan Patin (Pangasius sp.) Jurnal Teknologi Perikanan dan Kelautan, 5(2) November 2014: 183-190.

Heriadi, U. F. \& Mulyadi, Iskandar (2006). Increasing Calcium Carbonate (CaCO3) to Grot and Survival Rate Vanamei Shrimp (Litopenaeus vannamei). Aquaculture Technoogy Laboratory Faculty of Fisheries and Marine Sciences. University of Riau.

Jaedun, A. (2011). Metode Penelitian Eksperimen. Pelatihan Penulisan Artikel Ilmiah. LPMP Provinis Daerah istimewa Yogyakarta. http://staffnew.uny.ac.id/upload/1315693 39/pengabdian/metode-penelitianeksperimen.pdf

Liang,T., Gao, C. X.,Yang, L., Saijilafu, Yang, H. L. \& Luo, Z. P. (2017). Deterioration of the mechanical properties of calcium phosphate cements with Poly ( $\gamma$-glutamic acid) and its strontium salt after in vitro degradation. J Mech Behave Biomed Mater. 75: 190-196. doi: 10.1016/j.jmbbm.2017.07.026. https://pubmed.ncbi.nlm.nih.gov/2875030 0/ 
Setyowati, D. N., Hardaningsih, I. \& Priyono, S. B. (2007). Sintasan dan Pertumbuhan Benih Pasca Larva Beberapa Subspesies Gurami (Osphronemus goramy). Jurnal Perikanan (J. Fisch. Sci). IX (1): 149-153. https://journal.ugm.ac.id/jfs/article/view/7 $\underline{5}$

Sitanggang, M. \& Sarwono. (2007). Budidaya Gurami. Penebar Swadaya, Jakarta, p: 1112.

Standar Nasional Indonesia (2000). Produksi Benih Ikan Gurame (Osphronemus goramy, Lac) Kelas Benih Sebar. SNI 016485.3-2000.

Standar Nasional Indonesia (2006). Ikan gurami (Osphronemus goramy Lac.). SNI 017241-2006.

Kordi, M.G.H.K. (2012). Ekosistem Mangrove: Potensi, Fungsi, dan Pengelolaan. Rineka Cipta. Jakarta

Hossain, M.A, \& Yoshimatsu, T. (2014). Dietary Calcium Requirement in Fish. Aquaculture Nutrition. https://onlinelibrary.wiley.com/doi/10.11 11/anu. 12135

Nugraha, A. A., Yustiati, A., Bangkit, I., \& Andriani, Y. (2020). Growth Performane and Survival Rate of Giant Gourami Fingerlings (Osphronemus goramy Lacepede, 1801) with Potassium Diformate Addition. World Scientific News an International Scientific Journal. 103-104. www.worldscientificnews.com.

Sembiring, R.K. (1995). Analisis Regresi. Bandung: Penerbit ITB. https://iopscience.iop.org/article/10.1088/ 1748-9326/aaa273/pdf

Zainuddin (2010). Pengaruh Calsium dan Fosfor terhadap Pertumbuhan, Efisiensi Pakan, Kandungan Mineral dan Komposisi Tubuh Juvenil Ikan Kerapu Macan (Epinephelus fuscoguttatus). Jurnal Ilmu dan Teknologi Kelautan Tropis. 2(2):1-9. https://media.neliti.com/media/publicatio ns/101256-ID-none.pdf 